\title{
DREDGING UP MAWSON: IMPLICATIONS FOR THE GEOLOGY OF COASTAL EAST ANTARCTICA
}

\author{
by Elizabeth M. Truswell
}

(with seven text-figures and two plates)

\begin{abstract}
Truswell, E.M. 2012 (14:xii): Dredging up Mawson: implications for the geology of coastal East Antarctica. Papers and Proceedings of the Royal Society of Tasmania 146: 45-56. https://doi.org/10.26749/rstpp.146.45 ISSN 0080-4703. Research School of Earth Sciences, Australian National University, Canberra 0200, Australia. Email: etruswell@aapt.net.au
\end{abstract}

\begin{abstract}
During the 1911-1914 Australasian Antarctic Expedition samples of bottom sediment were dredged from a wide sweep of coastline extending from the main base at Commonwealth Bay, to the western edge of the Shackleton Ice Shelf. An earlier study showed these sediments to contain palynomorphs recycled from eroding sedimentary sequences. High concentrations of Permian, Jurassic to Early Cretaceous, and Cenozoic microfossils were present in three regions of the continental shelf, namely, offshore from the Shackleton Ice Shelf, from Cape Carr and from close to the Mertz Glacier. The findings of the earlier study are re-evaluated in the light of new information concerning the bathymetry of sampled areas on the continental shelf, the sub-ice topography of ice shelves and the Antarctic interior, and of sedimentary processes controlling the movement of palynomorphs on the sea floor. Data from the vicinity of the Shackleton Ice Shelf raise the possibility of sourcing some recycled material through sub-ice connections with the deep Aurora Subglacial Basin of the interior. From the George V Basin, west of the Mertz Glacier, new echo-sounding data show the dredges collected lie mostly on the edge of a steep trough parallel to the coast. Previous suggestions that Jurassic to Cretaceous sequences there correlate with those of the Otway Basin on the Australian margin are corroborated by recent seismic reflection data showing thick rift and pre-rift sequences offshore from the Adélie and Wilkes coasts. The relationship of these sequences to putative Mesozoic sequences within the inland Wilkes Basin is uncertain. Limited studies suggest that recycled palynomorphs in continental shelf sediments may lie close to the sites of their original deposition.
\end{abstract}

Key Words: Antarctica, Mawson, dredging, palynomorphs, recycling, continental shelf, ice shelves.

\section{INTRODUCTION}

The Australasian Antarctic Expedition of 1911-1914, under the leadership of Dr (later Sir) Douglas Mawson made enormous contributions to understanding the science of the Southern Ocean and the coastal margin of a wide sweep of East Antarctica. These contributions encompassed oceanography and meteorology, biology, and, perhaps reflecting Mawson's own background and enthusiasms, a particularly wide range of studies into the geology of the coastal region.

The scientific reports from the expedition were published over the period 1918-1942, delays in publication resulting from a number of factors - the First World War, the Great Depression, a lack of funding and Mawson's other commitments. Reports on aspects of the geology were wideranging, including, inter alia, studies of the metamorphic rocks of Adélie Land (Stillwell 1918,1923), the dolerites of Horn Bluff (Browne 1923), the dolerites and granites of King George Land (Summers \& Edwards 1940), a single meteorite (Bayley \& Stllwell 1923) and a host of studies on suites of metamorphic, igneous and sedimentary rocks from the moraines at Cape Denison, in the vicinity of Commonwealth Bay, where the expedition's main base was established (e.g., Coulson 1925, Glastonbury 1940).

Significantly, the earliest of the geological reports to be published were those by Frank Stillwell, who was a member of the main base party at Commonwealth Bay. Stillwell had recently graduated in engineering and science from the University of Melbourne (see Hince 2012 for a biography). His reports on the in situ metamorphic rocks of Adélie Land, and of amphibolites in erratics in the moraines of Cape Denison appeared in 1918 and 1923. The other geological reports, published in the 1920s and 1940 s, were written by academic geologists who were not members of the expedition. Mawson's own reports, on the narrative of the voyage, on sedimentary rocks collected by the expedition, and his extensive catalogue of all the rock specimens, did not appear until 1940.

While this plethora of reports constituted a major contribution to understanding the onshore geology of coastal East Antarctica, the other area in which substantial information of a geological nature was provided was through the soundings and dredgings made from the SY Aurora - a steam yacht built in 1876 primarily for whaling in Arctic seas. The area of the Antarctic coastline sampled from the Aurora extends from $146^{\circ} \mathrm{E}$ to $90^{\circ} \mathrm{E}$ longitude, from the main base near Cape Denison, to the quarters of the Western Party on the western edge of the Shackleton Ice Shelf (fig. 1).

In 1982, the centenary of the birth of Douglas Mawson, I was able to obtain some 53 dredge samples recovered from the driver tubes in the taking of depth samples on all three Antarctic voyages of the Aurora (Truswell 1982). The samples were processed to recover palynomorphs (spores, pollen and dinoflagellate cysts) that have been recycled into these surficial, or essentially Recent, muds by the erosion of sedimentary sequences on the continent or on the continental shelf by glacial or submarine processes. The distribution of these palynomorphs proved to be a useful tool in suggesting the position, age and depositional environment of sedimentary sequences hidden beneath ice cover.

The purpose of the present paper is to re-evaluate the significance of the distribution of the recycled palynomorphs in the light of current information relating to the geology of the coastal margin of East Antarctica. Specifically, three questions might now be asked. First, how do the data fit with contemporary understanding of the bathymetry of the continental shelf? Second, can the data be reconciled with what is now known of the sub-ice geology of inland 


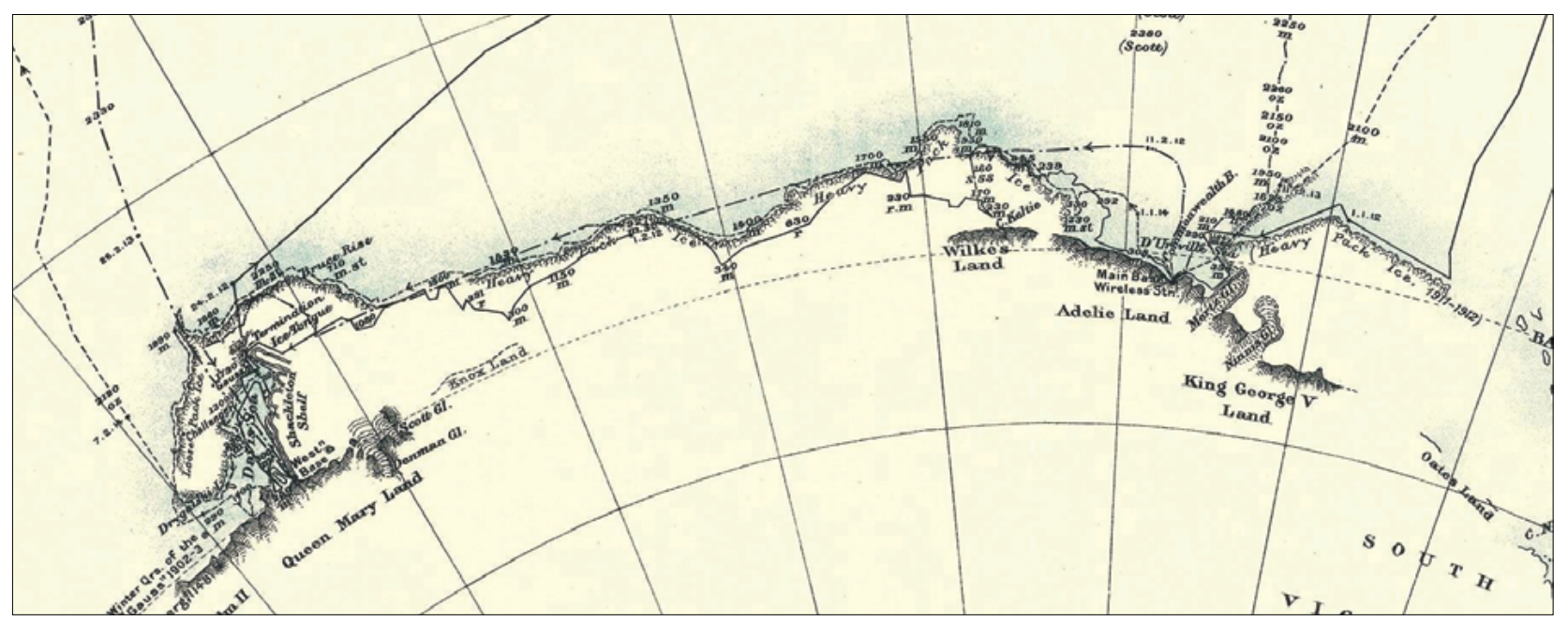

FIG.1 - Extract from Mawson's (1914) map of the East Antarctic coastal region, showing location of the main base at Commonwealth Bay, the Western Base near the Shackleton Ice Shelf, plus the tracks of the three Antarctic cruises, and of overland traverses.

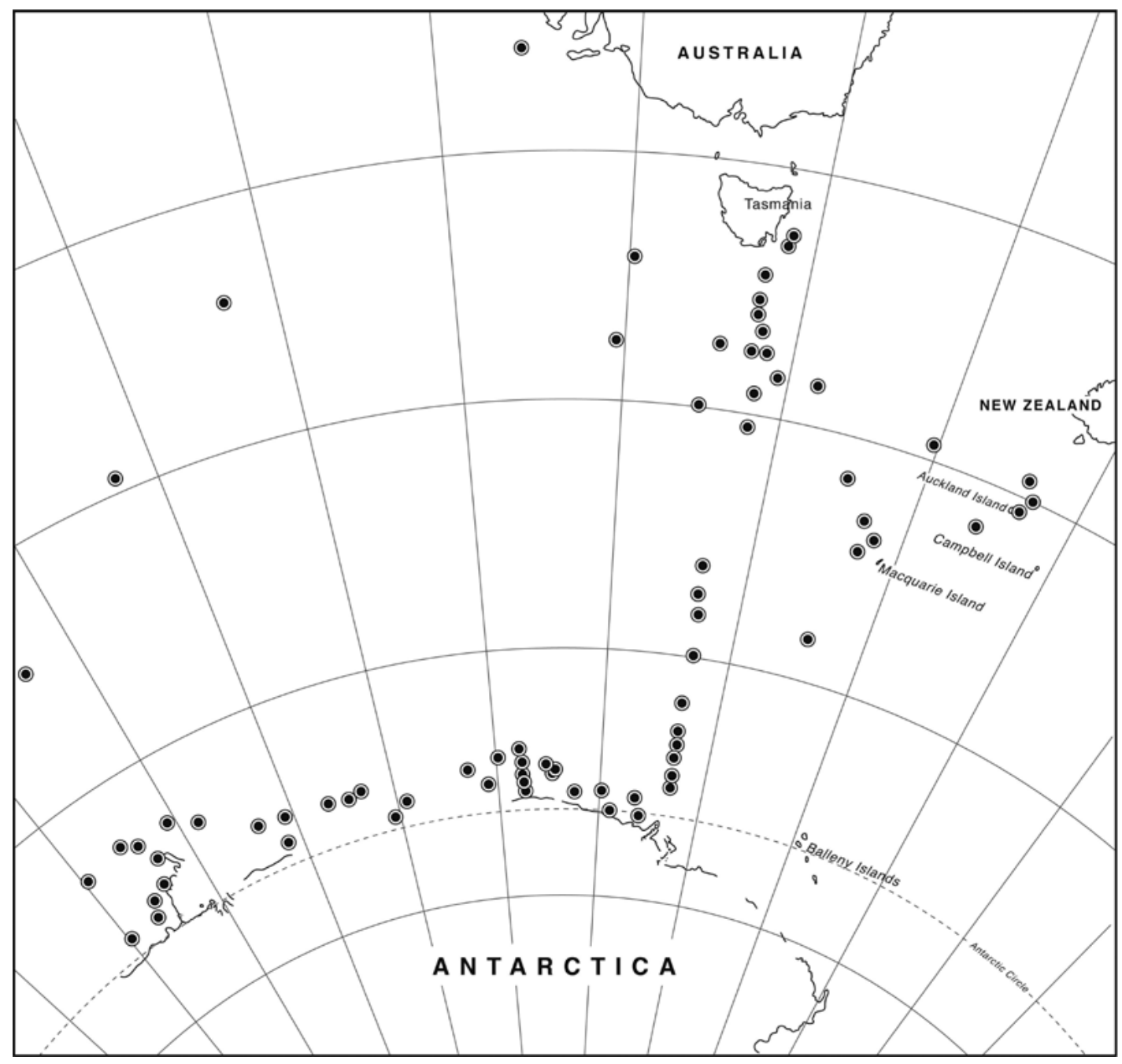

FIG. 2 - Southern Ocean showing location of soundings and dredgings on all Antarctic and sub-Antarctic cruises of the SY Aurora. Simplified from Chapman (1922). 
Antarctica that impinges on the coast? Third, do we better understand the way in which these microfossils are moved around on the sea floor by sedimentary processes?

\section{SOUNDINGS AND DREDGINGS}

The operation of the deep-sea work of depth sounding and bottom sampling was carried out under the direction of Captain John King Davis FRGS, captain of the Aurora, and second-in-command of the expedition. In his report, published in 1939, Davis gave detailed descriptions of the types of machines employed by the ship's sounding party - a small band of crew members whom Davis described as "cheerful and energetic enthusiasts, ever ready for action, and reliable under the most trying conditions" (Davis 1939, p.91).

Depth soundings, and in many cases, sampling of bottom sediments, were carried out on all cruises of the Expedition, namely, the three Antarctic cruises, and two cruises in subAntarctic waters. The first cruise left Hobart in December 1911 , but, owing to the crowded state of the decks of the Aurora on that first voyage, soundings were not taken until the ship neared the Antarctic coastline on 3 January 1912. Localities of the soundings are shown in figure 2. Davis reported that "The depth of the sea was obtained by one or other of two types of machine: for deepwater to depths of 6000 fathoms a Lucas sounding machine was employed; for depths of up to about 200 fathoms the Kelvin sounder was employed" (Davis 1939, p.91).

Two Lucas machines were used, one each on the port and starboard sides of the vessel. An example of the ready cooperation among explorers of this "heroic era" of Antarctic exploration is shown by the fact that a brass steam winding engine, used to wind in the wire on the port side sounder, was loaned to the party by Dr W.S. Bruce, leader of the 1902-1904 Scotia Expedition into Antarctic waters. The Lucas machine (pl. 1) consists of a central drum holding up to 6000 fathoms of tightly coiled wire passing out over a measuring wheel, where the length of wire, and hence the depth, is recorded directly on a clock-faced dial.

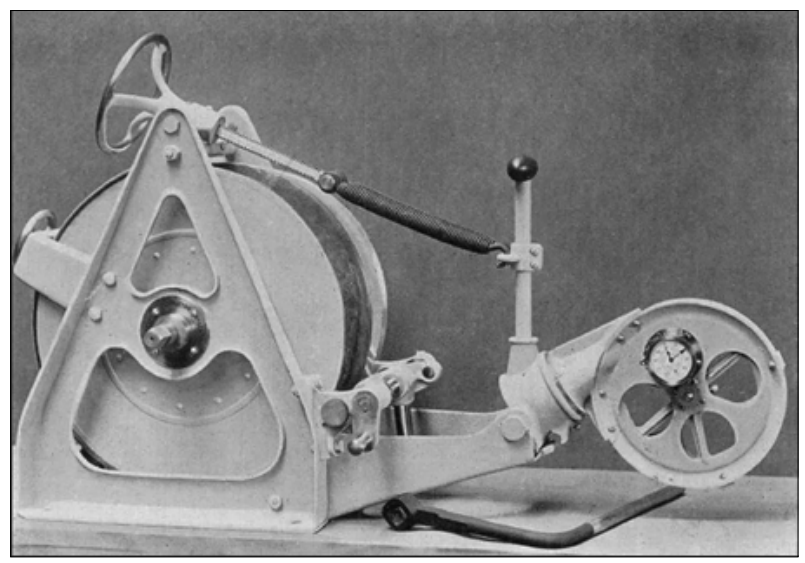

PLATE 1

The Lucas automatic sounding machine. (From J.K. Davis. Soundings. AAE Reports, Series A, vol. II, Plate VII.)
Where it was desirable to take samples of the sea floor, a driver, or hollow steel tube, was spliced on to the end of the sounding wire with a hemp line. Ring-shaped iron weights control the driver's impact on to the sea floor, and the sample obtained is retained within the tube by a valve, which closes, allowing mud or ooze to be brought safely to the surface (pl. 2). This device was similar to the Baillie sounding machine used on the cruise of HMS Challenger (1872-1876). Soundings taken in this way required the vessel to be stopped and turned to face the wind, to be kept as near stationary as possible. Inevitably, however, strains imparted by heavy swells in the Southern Ocean meant that some failures occurred.

The Kelvin sounding machine, employed for shallow water depths, and mounted on the after-deck of the Aurora, was similarly based on a drum whereon wire was paid out and depths measured on a graduated dial. In this case the wire was retrieved using hand power. The mechanism employed by this device meant that soundings could be taken while the ship was still steaming along.

Trawling was a much more complex and time-consuming operation than sounding and dredging, and was primarily carried out to recover biological materials. The Aurora carried a Monegasque trawl, named for the Prince of Monaco, Albert I, who had a keen interest in oceanography. Trawling with this apparatus required a wooden derrick and a steam windlass to drag a wide-mouthed net over the bottom, for periods of an hour or more. While the emphasis of this operation was clearly on biological investigations, comments from Mawson (1915, p.407), show that geological factors sometimes interfered with the biology. He wrote: "Unfortunately for biological considerations, our catches often partook too much of a geological character; stones great and small, several of which hauled on board actually weighed half a ton each, were most unwelcome items, for they tore the net and crushed the contents. It was thus ascertained that the oozy floor of the sea in those waters is abundantly sprinkled with rocks which arrived at their present resting place upon release from icebergs, embedded in which they had floated out from the land. Each stone

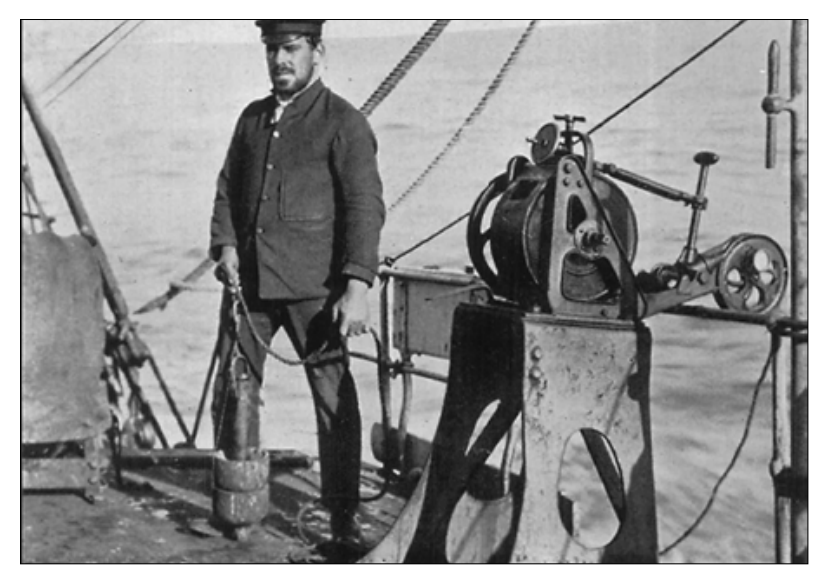

PLATE 2

The Lucas machine with Chief Officer Fletcher holding up the driver loaded with annular weights, ready to obtain a bottom sample and depth determination. (From J.K. Davis. Soundings. AAE Report Series A, vol. II, Plate VII.) 
showed just how far it had been sunk in the mud, for the upper protruding part was blackened with a curious deposit of manganese oxide".

Curiously, there is little information on the fate of the rocks collected in this manner. No record of them appears in Mawson's catalogue of the rocks collected on the expedition (Mawson 1940a) nor are they dealt with in his account of the sedimentary rocks (Mawson 1940b). One exception, however, is the report of the dredging of several small specimens of lignite or brown coal at two sites off the west side of the Mertz Glacier Tongue. Speculatively, Mawson (1940b) considered that these might be from either brown coal beds in place on the sea floor, or else transported from the land with other debris from moraines. These lignites now appear to be lost.

In spite of the loss of this material, it is of historical interest to note here the circumstances of their dredging. This was on the last voyage - the homeward voyage of the Aurora. Mawson (1915, p.405) wrote: "It was a miserable Christmas Day, and a little better on the 26th. That afternoon, however, it cleared sufficiently to reveal a hazy view of the coast. By $10 \mathrm{pm}$ the wall of the Mertz Glacier Tongue was visible on the port bow...Allowing a day for the weather to become clearer and more settled, we got out the trawl and made a successful dredging in three hundred fathoms close to the glacier tongue. In addition to the usual items, several fragments of fossilized wood and coaly matter were discovered in the oozy mud that came up in quantities with the catch".

The lack of records of the rest of the dredged rocks is surprising in that it should have been apparent, particularly to a geologist of Mawson's calibre, that valuable information might have been derived from this material in understanding the geology of both inland and coastal regions of East Antarctica. The value of clasts recovered recently from dredge hauls of glaciomarine sediments has been demonstrated in a number of contemporary studies, which have used petrographic and geochemical data (especially $\mathrm{U}-\mathrm{Pb}$ zircon age studies) to identify the area and age of source sequences beneath inland ice cover. For example, clasts from the Wilkes Land margin, including some from regions covered by Mawson, such as that close to the Mertz Glacier, have provided key insights into the Precambrian basement of the East Antarctic Shield inland from this coast (see Domack 1982, and summaries in Goodge \& Fanning 2010, Veevers \& Saeed 2011).

The nature of the sea-floor deposits recovered from the driver tubes of the Lucas machine was described in detail in the report series by the palaeontologist Frederick Chapman (1922). In addition to brief descriptions of the bottom samples, including bathymetry, physical characteristics, organic content, and short descriptions of the foraminiferal genera encountered, Chapman provided some generalised comments about the distribution of sediment types. For example, during the second Antarctic cruise, roughly along the meridian of $146^{\circ} \mathrm{E}$, he noted that the series of samples showed well a gradation of sediment type from calcareous Globigerina ooze in the northern sector, through diatomaceous and spicular oozes to terrigenous oozes off the Antarctic margin.

\section{PALYNOLOGICAL ANALYSIS OF THE SEA- FLOOR SEDIMENTS}

The samples examined in the 1982 study were from collections held by the Australian Museum in Sydney, although, as noted, the lignites mentioned by Mawson from the Mertz Glacier region could not be found. In that study, data from Mawson's dredge samples were supplemented by material from the tops of piston cores taken from Cruise 37 of the USNS Eltanin in 1968.

Within the sampled region, extending from the main base at Commonwealth Bay to the quarters of the Western Party on the western edge of the Shackleton Ice Shelf, concentrations of recycled palynomorphs were high at three localities - high enough to suggest that eroding sedimentary sequences were not far distant from the sites of deposition. These points of concentration were: the western side of the Shackleton Ice Shelf; an area on the western side of the Mertz Glacier tongue; and a region to the east of Cape Carr. Details of the assemblages, listing palynomorph taxa and their known stratigraphic ranges, were given in Truswell (1982) and are only briefly summarised here. More comprehensive lists of the taxa identified were given in Truswell (1983), together with illustrations. In the 30 years since the publication of the 1982 paper, considerable advances have been made in understanding the stratigraphic ranges of a number of palynomorph taxa, particularly in Australian sedimentary sequences. Where relevant, comments noting these refinements in age ranges have been incorporated below.

\section{SHACKLETON ICE SHELF}

The Shackleton Ice Shelf, named by Douglas Mawson, is one of the largest ice shelves on the East Antarctic margin, extending for some $385 \mathrm{~km}$ off the coast between longitudes $95^{\circ} \mathrm{E}$ and $105^{\circ} \mathrm{E}$. It was encountered by the US Exploring Expedition under Charles Wilkes in 1840; after his long exploration from the east along the ice-bound coast, Wilkes retreated and turned north at what he termed "Termination Land". Figure 3 (redrawn from Mawson 1942) shows "Termination Tongue" as part of the ice shelf. It also shows the position of the small Helen Glacier in the west, and the larger Denman Glacier to the east - the latter proving a barrier that members of Mawson's Western Party under Frank Wild were unable to cross because of its intense crevassing. A more recent analysis of continental ice drainage into the Shackleton Glacier (Urbini et al. 2010) is discussed below.

In the 1982 study, samples dredged from the Aurora near the seaward end of the Shackleton Ice Shelf (Samples $141,141 \mathrm{~A}, 141 \mathrm{~B}, 142)$ were the most productive of all, yielding palynomorph densities between 1500 and 2000 grains per gram of sediment. These recycled microfossils fall into three broad age groups: Permian, Late Jurassic to Early Cretaceous, and Late Cretaceous to Early Cenozoic. The species identified are listed in Truswell (1982, Tables 1-3). All show good to excellent preservation, indicating that levels of organic metamorphism are low to moderate, and suggesting that that they have been neither deeply buried nor affected by thermal metamorphism associated with igneous intrusion.

The Permian element observed here is of particular interest. It is among the best-preserved known to date from Antarctica. While Permian palynomorphs are common in 


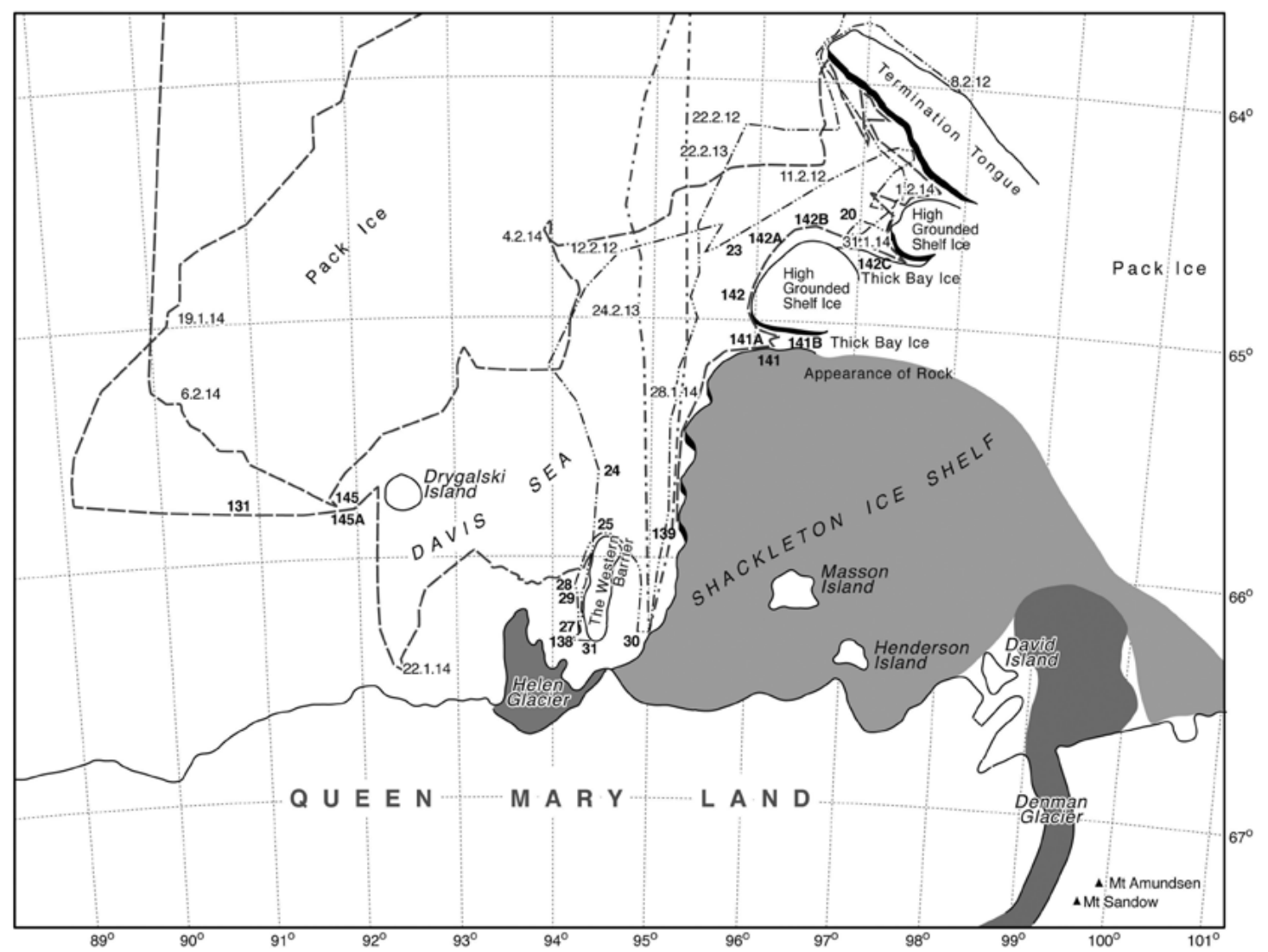

FIG. 3 - Map of Shackleton Ice Shelf area redrawn after Mawson (1914, 1942) and Truswell (1982). Geographic features labelled from Mawson, as are routes of SY Aurora; sample numbers after Chapman (1922).

all of the dredged samples, they are most abundant in the southern part of the area - in samples 25 and 39 they make up 33\% and 55\%, respectively, of total palynomorph counts. Within this non-marine assemblage, some taxa are held in common with those known from the Amery Group of the Prince Charles Mountains, exposed in the Lambert Graben, inland from Prydz Bay, far to the west of the Shackleton Ice Shelf. However, there is an element in the recycled assemblage that suggests erosion from beds that are older than any known from that sequence. The palynology and biostratigraphy of the Amery Group was reviewed by Playford (1990), who considered that assemblages described by a number of authors from the exposed formations of that Group (Radok Conglomerate, Bainmedart Coal Measures, Flagstone Bench Formation) were essentially of Late Permian age - equivalent to his Praecolpatites Zone of Antarctica or to Stage 5 of the Australian Permian. An extension of the Amery sequence into the Late Triassic - on the basis of palynology - was described by Foster et al. (1994).

Within the recycled assemblage offshore from the Shackleton Ice Shelf, several observed species are restricted to, or most common in, palynological assemblages referred to as Stage 2, or Stages 3-4, in Australia, or their equivalents in the Parasaccites and Protohaploxypinus Zones in Beacon Group sequences of the Transantarctic Mountains (see Playford 1990), which are probably of Early Permian and possibly Late Carboniferous age. Palynomorphs from that sequence, however, are darkened and corroded, having suffered severely from thermal metamorphism associated with intrusion of the Ferrar Dolerites. This contrasts with the excellent preservation of the recycled material. Sources for the Permian elements in the Shackleton Ice Shelf dredges are speculative, but some possibilities are canvassed below. The most diverse element among the recycled palynomorphs in the area was assigned to the Late Jurassic to Early or Mid Cretaceous (Truswell 1982). A more precise breakdown of the possible age ranges of units within the eroding source beds that may have contributed these palynomorphs was based on known age ranges of selected species in Australian sedimentary basins, but some caution should be emphasised here in that ranges may not be precisely parallel in Antarctica. Both quantitative data - general abundance of major groups - and the ranges of selected individual species suggest that beds of Late Jurassic through to Albian ages may have been included within the source beds. Updating of the palynostratigraphy of Australian basins confirms these original age assignments. For instance, the appearance of the spore species Coptospora paradoxa (Cookson \& Dettmann) defines the base of a nominate zone in Australia to which an Early to Lower Late Albian age range has been assigned (see Helby et al. 1987). The associated species Trilobosporites trioreticulosus Cookson \& Dettmann, also present in the Shackleton Ice Shelf samples, similarly defines the base of that zone, confirmed by recent studies in Australia's Gippsland Basin (Wagstaff et al. 2012). Elsewhere in East Antarctica, sediments referred to the $C$. paradoxa Zone were reported from DSDP Site 741, in Prydz Bay (Truswell 1991). This putative Cretaceous sequence appears to have been primarily non-marine, although a single Cretaceous dinocyst hints at a minor marine component.

The third element in the area, of Late Cretaceous to Early Cenozoic age, includes a suite of well-preserved dinoflagellate cysts as well as a distinctive pollen assemblage. Dinocysts are most abundant in the dredge samples labelled 141 
and 142 . Some of these typify what has been referred to as the "Transantarctic Flora". This assemblage consists of a number of species that appear to have been endemic to high southern latitudes; several authors have reviewed this flora (see for example Wrenn \& Hart 1988, Truswell 1999, Levy \& Harwood 2000). Most recently, Bijl et al. (2011) investigated the spatio-temporal distribution of endemism in high-latitude dinocysts, and observed that a switch from cosmopolitan-dominated to endemic-dominated assemblages occurred around the Early-Middle Eocene boundary, perhaps in response to nutrient availability linked to ocean circulation changes. The prevalence in the Shackleton Ice Shelf assemblages of species such as Arachnodinium antarcticum Wilson \& Clowes and a distinctive suite of Deflandrea species identifies these assemblages as belonging to this endemic flora. Further, some species, including $A$. antarcticum, are known to have major abundances in the Middle Eocene; the species is the nominate taxon for a dinocyst range zone of this age in the Gippsland Basin of southeastern Australia (Partridge in McGowran et al. 2000). Tentatively, these age distributions suggest that at least part of the eroding marine sequence contributing palynomorphs to the Shackleton Ice Shelf is of Middle Eocene age.

Pollen assemblages from these dredge samples contain taxa characteristic of Late Cretaceous to Eocene sequences in Australia, and from Eocene sediments drilled in Prydz Bay, Antarctica (Truswell \& Macphail 2009). Assemblages typically contain a diversity of pollen related to that of modern Nothofagus, a limited suite of proteaceous forms, and species assigned to the form genus Gambierina, of unknown affinity.

\section{MERTZ GLACIER REGION}

In this area the Australasian Antarctic Expedition made its first landfall in January 1912, west of the Mertz Glacier Tongue. The first dredge sample, labelled A, was taken at $65^{\circ} 52^{\prime} \mathrm{S}, 143^{\circ} 39^{\prime} \mathrm{E}$, and was retrieved from the edge of the continental shelf in the area. Subsequently, a number of samples were dredged close to the western edge of the Mertz Glacier. Productive samples in the area yielded, on maceration, spores and pollen predominantly of Early Cretaceous age. Included among the stratigraphically useful taxa identified was Pilosisporites notensis Cookson \& Dettmann which is the nominate form for a palynozone of Aptian age in southern Australian basins (see for example Morgan et al. 1995), although the species ranges from the Late Neocomian into the basal Albian in the Gippsland Basin (Wagstaff et al. 2012). Forms more characteristic of the Albian in southern Australia were not observed here. The Early Cretaceous palynomorph suites obtained from the Aurora dredges are very similar in composition to assemblages recovered from an in situ brecciated siltstone retrieved by piston coring in the George V Basin, west of the Ninnis Glacier during Operation Deep Freeze in 1979 (Domack et al. 1980), and assigned a probable Aptian age on the basis of comparison with then known ranges in Australian sedimentary basins.

Present in lower frequencies were Late Cretaceous to Early Cenozoic taxa. A single grain of Permian age was recorded.

\section{CAPE CARR AREA}

A high concentration of recycled palynomorphs was recovered from an area lying off the edge of the continental shelf, slightly to the east of Cape Carr, an ice-covered cape named by Charles Wilkes of the US Exploring Expedition for Lieutenant Overton Carr of the Vincennes (Wilkes 1844). Mawson (1942), reporting in the narrative of the voyage (23 January 1912), noted that the ship's log stated that a sharp lookout was being kept for the land reported in 1840, but none was seen, and the Aurora had sailed over the site of Wilkes' Cape Carr (now designated as $66^{\circ} 7^{\prime} \mathrm{S}$; $130^{\circ} 43^{\prime} \mathrm{E}$ ).

The recycled material in the dredge samples taken off the edge of the shelf contains spores and pollen of Early to mid Cretaceous (? Albian to Cenomanian), and Late Cretaceous to Early Cenozoic ages; no Permian forms were recorded (Truswell 1982). Perhaps curiously, dredge samples on the shelf proper are nearly barren of recycled material, leading to the tentative suggestion that the recycled material may be eroding from strata cropping out on the steep slopes of the shelf break. While no new data have become available on the bathymetry or geology of this area since the 1982 study, the suggested presence there of sequences of Albian age is in line with ages suggested for the Shackleton Ice Shelf, and, more recently, for sequences offshore from Prydz Bay (Truswell 1991).

\section{RELATIONSHIP TO BATHYMETRY, SUB-ICE TOPOGRAPHY AND GEOLOGY}

Since the publication of the initial report on the distribution of the recycled palynomorphs in the dredge samples from the Aurora (Truswell 1982), there has been a number of advances in understanding the bathymetry of the continental shelf in parts of East Antarctica, and of the position of putative sedimentary basins on the continent that impact on the coastal margin. In some cases the palynomorph distributions appear to be clarified by the local bathymetric and geological setting; in others they raise questions that require further investigation. The two areas where data from these different sources intersect are in the vicinity of the Shackleton Ice Shelf, and of the Mertz Glacier off George V Land. No new data are available from the Cape Carr region.

\section{SHACKLETON ICE SHELF}

The distribution of palynomorphs in this area is outlined above. The relationship of these to the continental shelf bathymetry remains largely unknown, as the inaccessibility of the area has precluded major surveys. The bathymetry as shown in the 2008 Gebco map shows the tracks of ships collecting echo sounding data, and highlights the general lack of information on the continental shelf (fig. 4). However, a recent compilation of radio-echo sounding data from the Shackleton Ice Shelf does shed some light on the outlet glaciers flowing into the ice shelf, and on grounding lines within the shelf, all of which may be relevant to palynomorph distribution (Urbini et al. 2010). The small Helen Glacier on the western margin of the ice shelf appears to drain a continental area wherein no sequences younger than Cambrian are known. Among a number of glaciers draining into the eastern part of the ice shelf the Denman Glacier is the fastest and 


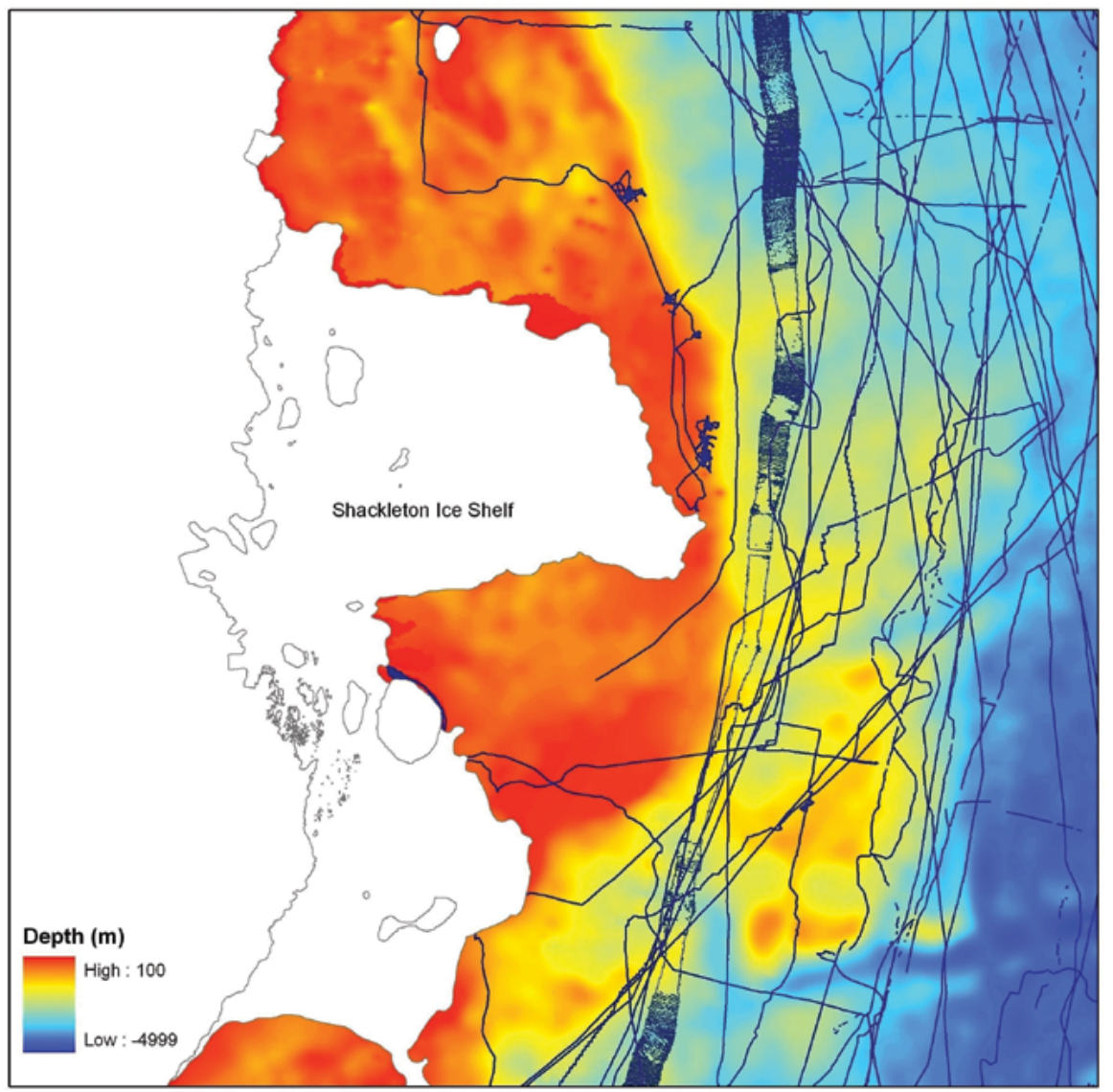

FIG. 4 - Shackleton Ice Shelf and surrounding continental shelf, with ship tracks showing all available single beam and multibeam echo-sounding data available for the area. The one multibeam survey line is the $N-S$ trending line with the squiggles inside it just off the shelf break. This survey was conducted by the R/V Roger Revelle in 2007 (survey CLIVAR/I8S). (From GEBCO_08 grid, version 20100927. See http:www.gebco.net)

thickest (Urbini et al.2010). While heavy crevassing has made definition of its valley contours difficult, it appears that the Denman Valley, bedrock to the Denman Glacier, may be up to $9 \mathrm{~km}$ wide and up to $2 \mathrm{~km}$ deep at the grounding line.

A clearer understanding of the sub-ice topography of inland Antarctica has been achieved in recent years through a combination of direct studies of ice thickness and modelling (Lythe et al. 2001, Roberts et al. 2011). Of possible relevance to sediment deposition in the Shackleton Glacier region is the definition of the Aurora Subglacial Basin. Roberts et al. (2011) presented a new reconstruction of the thickness of the ice sheet over parts of East Antarctica, using ice thickness measurements in combination with digital elevation modelling to derive the elevation of the base of the ice sheet. In so doing they defined the Aurora Subglacial Basin (fig. 5) as a large area where the base of the ice lies below present sea level, with deep submarine connections from the deep interior to the coastal zone. The Denman Glacier and the Totten Glacier have been identified as likely drainage outlets. Given this scenario, it is possible that the source of Permian material deposited near the Shackleton Ice Shelf may originate within the Aurora Subglacial Basin, but this remains a tentative suggestion.

Further, reconstructions between Antarctica and Australia, which are based on Precambrian basement provinces, show that part of the Shackleton Ice Shelf region abutted the southern part of the Perth Basin of southwestern Australia (see for example Fitzsimons 2003). There, the Sue Group represents a thick Permian section, where the Sue Coal Measures are overlain by Late Permian to Early Triassic Sandstones. It has been suggested that the Darling Fault of the Perth Basin may correlate with the Denman and Scott glaciers (see Fitzsimons 2003, Fig. 8). Given the possibilities presented by this reconstruction, the presence of eroding Permian sequences in this region of coastal East Antarctica would not be unexpected.

\section{GEORGE V BASIN-MERTZ GLACIER REGION}

The bathymetry of the offshore area where the Aurora dredge samples were collected is now better understood than it was in Truswell's 1982 study. There is now a higher density of digital bathymetric data available in this area than for other parts of East Antarctica. Beaman \& Harris (2003) used echo-sounder data to establish the presence of a linear, inner shelf trough that lies parallel to the coast; they identified drifts of sediment lying to the west of the Mertz Glacier. The definition of these inner shelf basins was further improved by Beaman et al. (2010) using a combination of single and multibeam surveys, coastline data, and land and ice-sheet data to present a more refined bathymetric grid. The inner shelf depressions have been variously referred to as the George V 


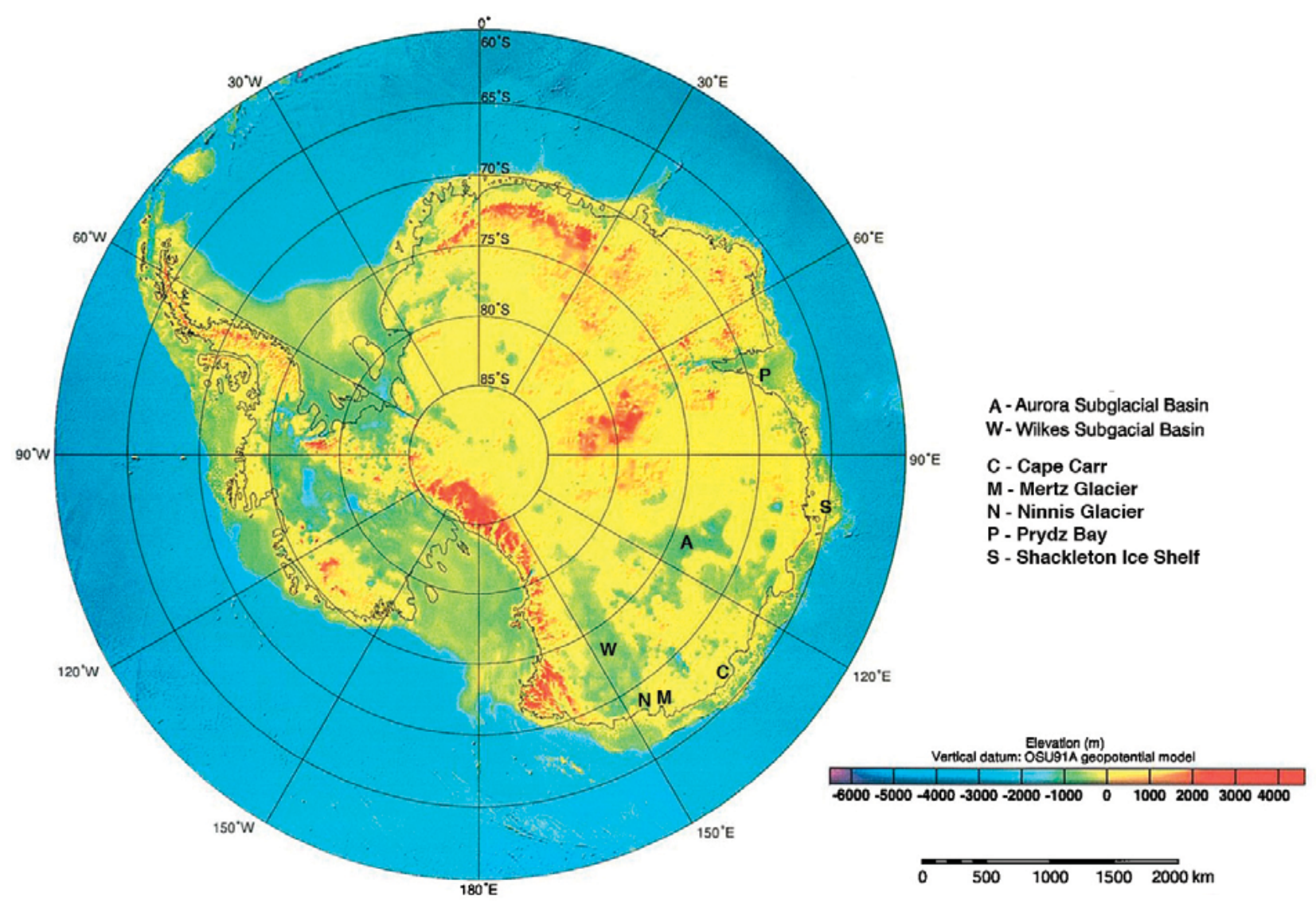

FIG. 5- Sub-ice sedimentary basins, adapted from Lythe et al. 2001, plate 1. Major sites discussed in the text are also shown.

Basin, the Adélie Depression, or the Mertz-Ninnis Trough (figs 6,7). This trough appears to extend to the east of the Mertz Glacier, but its topography is less well defined there due to scarcer data. Inner shelf troughs such as these are a feature of the East Antarctic margin, and may originate in Cenozoic fault traces that have been scoured and deepened by glacial action (Vanney \& Johnson 1979).

The dredge samples collected from the Aurora that have been plotted on the recent bathymetric maps show that they were collected in part on the seaward edge of the Mertz-Ninnis Trough. These are the samples that yielded predominantly non-marine Early Cretaceous assemblages, and marine Late Cretaceous to early Cenozoic taxa (see above). An Early Cretaceous (Aptian) age was recorded too from the depression to the east of the Mertz Glacier (Domack et al. 1980). Further dredging, carried out during 2001 by the NB Palmer recovered sedimentary clasts from the seaward flank of the Mertz-Ninnis Trough. These yielded palynomorphs of Paleogene and Early Cretaceous age (Schrum et al. 2004); combined seismic data suggest that these represent seafloor outcrop or shallow subcrop sequences.

The available information suggests that the George V Basin (or Mertz-Ninnis Trough) is a deep depression similar to others that lie on the continental shelf parallel to the coast of East Antarctica between $90^{\circ}$ and $150^{\circ} \mathrm{E}$ (Domack et al. 1980, Domack 1985). The established presence of Cretaceous and Cenozoic strata within this basin invites comparison both with basins on the southern margin of
Australia, and with intracratonic basins on Antarctica, inland from this coastal region. The suggestions made by Domack (1985) and Truswell $(1982,1983)$ that palynomorph-rich sequences offshore from the Wilkes Land coast of Antarctica have their equivalents in sedimentary basins of the Great Australian Bight are confirmed and elaborated by recent seismic reflection data and sedimentology of the Antarctic margin (Close et al. 2007).

Seismic sequences in an area offshore from Wilkes Land and Terre Adélie, immediately to the west of the George V Basin, show the presence there of two major sedimentary basins, containing more than $9 \mathrm{~km}$ of sediments. Thick rift and pre-rift sequences are interpreted to be of Late Jurassic to mid-Cretaceous age on the basis of seismic correlation with the Australian margin. Reviews of the nature of the Australian margin (see for example Brown et al. 2003) show that rift stage sediments of Jurassic to mid-Cretaceous age extend through a number of sedimentary basins and subbasins, including, from west to east, the Bremer Basin, Great Australian Bight Basin, Duntroon Basin, Otway and Sorell basins. On the Antarctic margin, sediments of this age have only been directly sampled in the George V Basin (Domack et al. 1980), but may be represented by the assemblages of recycled palynomorphs from the Shackleton Ice Shelf, Cape Carr and the Mertz Trough. These assemblages are essentially non-marine in character.

Post-rift sediments, which are concentrated in a major depocentre off west Wilkes Land, contain sequences of Late Cretaceous to Paleogene and younger sediments. 
FIG. 6 - George V Basin, offshore from George $V$ Land, showing shelf bathymetry and location of Aurora dredge samples as documented by Chapman (1922). Dark shading on the shelf represents a ridge facies identified by Beaman \& Harris (2003). Sample $A$ at the shelf edge, is the first dredge taken on the Expedition. (Modified from Beaman o Harris (2003, fig. 2).)

FIG. 7 - Bathymetric map of George V continental margin, based on single beam and multibeam echosounding data, showing the deep trough lying parallel to the coast and adjacent to the Mertz Glacier (From Beaman et al. 2010, fig.1a.)
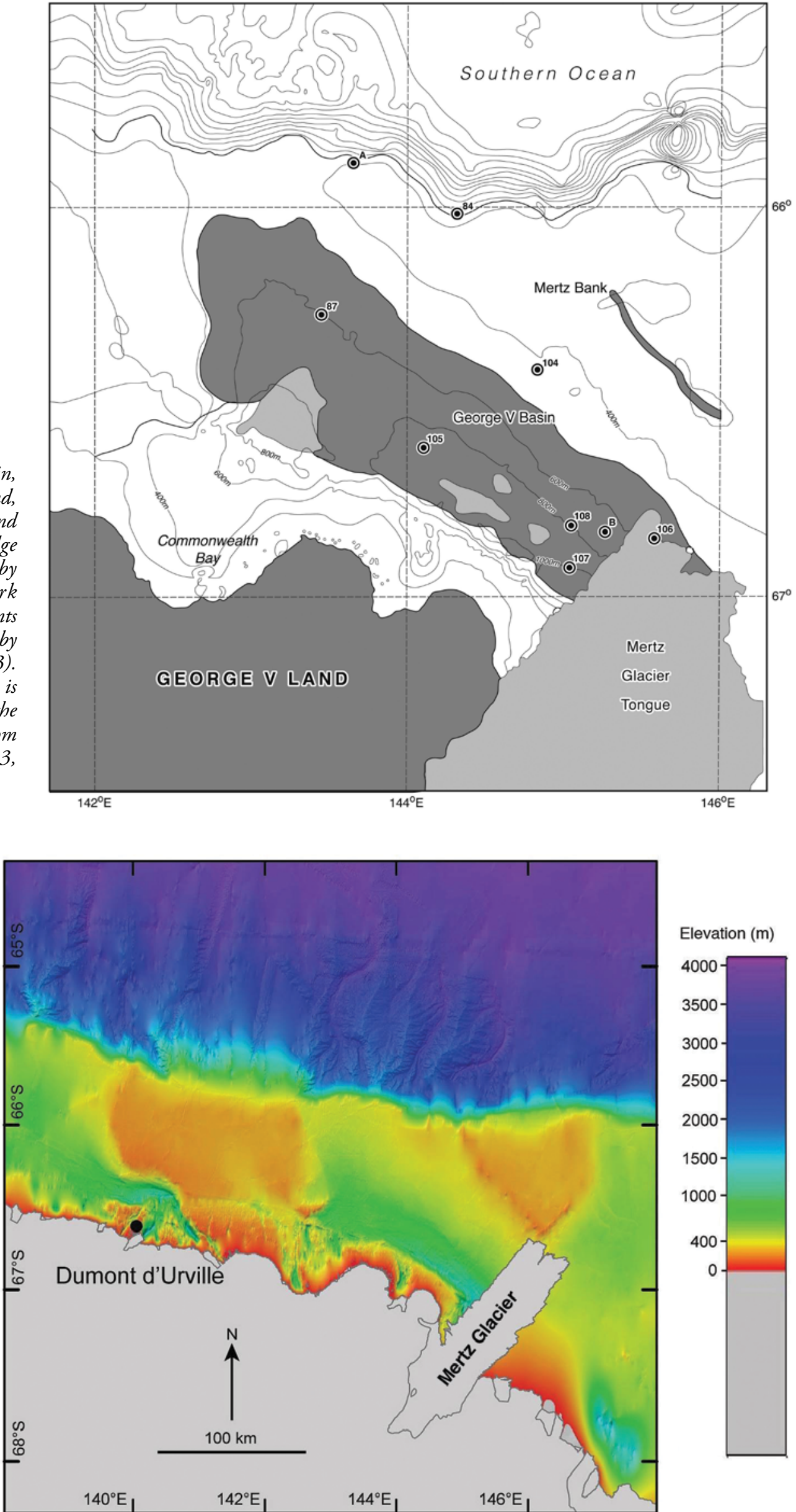
While the Cretaceous and Paleogene sediments inferred from the recycled palynomorphs off the Mertz Glacier Trough lie slightly to the east of the seismic study area, they are likely to represent the same post-rift sequences. The relationship of the Antarctic basins to those of the Australian margins, as interpreted from the seismic data, and using oceanic fracture zones and seismic anomalies (see Close et al. 2007, Fig. 1) confirms the suggestion that the George V Basin sequences should be conjugate with those of the Otway Basin of southern Australia, although they would lie slightly to the west of that basin, in the area of the Beachport Plateau (Beachport sub-basin).

The possibility that major sedimentary basins in the hinterland of East Antarctica may intersect the coast in the region of the Mertz and Ninnis glaciers was explored in the 1970 s and 1980s by Drewry (1976) and Steed \& Drewry (1982), and noted in Truswell (1982). Reconnaissance airborne radar data were used then to define the Wilkes Subglacial Basin as a major, $1400 \mathrm{~km}$-long subglacial depression, with its maximum width of $600 \mathrm{~km}$ occurring at the George V Coast. These early studies gave rise to speculation that the Wilkes Subglacial Basin contained Beacon Supergroup sediments overlain by significant thicknesses of Mesozoic and Cenozoic sediments.

New aeromagnetic and airborne radar data (Ferraccioli $e t$ al. 2009) have shown this subglacial basin to be extremely complex in terms of sub-ice topography and inferred geology. That study, based essentially on detail of the central part of the basin, reveals a number of sub-basins, which contain, inter alia, Jurassic dolerites of the Ferrar Group, but indicates that there is little likelihood of any significant thickness of post-Jurassic sediments. Such younger sedimentary infill, if it exists, is likely to be localised and thinner than originally suggested by Drewry (1976).

However, it should be noted that the data remain sparse for localised basins in the western margin of the larger subglacial basin, and the nature of aeromagnetic anomalies there (including in the coastal region) could be explained by the presence of post-Jurassic sedimentary infill. The larger, "continent-scale" evaluations for the nature and thickness of the basin infill thus do not appear to rule out more localised sedimentary basins impacting on the George V coast.

\section{SEDIMENTARY PROCESSES AND DISTRIBUTION OF RECYCLED PALYNOMORPHS}

The value of reworked palynomorphs as a basis for determining the provenance of sedimentary sequences was discussed by Batten (1991), who pointed out that these microfossils have largely been under-utilised as a tool in stratigraphy. In his review, Batten drew attention to the application of the recycled palynomorphs in Antarctic shelf sediments, noting that these represent an exception to this generalisation.

Palynomorphs recovered from superficial sea-floor sediments on the Antarctic margin must originate from the erosion of sedimentary sequences cropping out either on the adjacent continent, or on the sea floor itself. Processes relevant to their distribution will clearly vary depending on local conditions, such as sea-floor topography and the proximity, or otherwise, of ice shelves. Bottom currents are likely to be a major factor controlling the microfossil distribution. A range of factors will thus influence the observed distributions, and processes will differ between individual sites.

However, two studies suggest that - at least in some cases - the assemblages of palynomorphs are not redistributed very far from the site of their initial deposition on the sea floor, and hence from their source areas. In the Ross Sea, for example, a quantitative study of palynomorph distribution (Truswell \& Drewry 1984) suggested that palynomorphs, which have their source in sequences below the Ross Ice Shelf, have initially melted out of sediment beneath the shelf, probably close to the grounding line. In this region, concentrations appear to be closely related to particular ice streams. Past advances of the shelf have "bulldozed" the pollen-bearing sediment seaward. Thereafter, however, bottom currents appear to have had only a minor role in their redistribution, as microfossils from East and West Antarctica remain in clearly separate areas on the Ross Sea floor (see Truswell \& Drewry 1984, Fig. 1).

A second area that also suggests minimal distribution of recycled palynomorphs by bottom currents occurs on the Mac.Robertson Shelf, to the west of Prydz Bay. There, palynomorphs ranging in age from Early Jurassic to Early Cretaceous were recovered from shallow drilling that penetrated Quaternary sediments in the arcuate trough that is the Neilsen Basin. The palynomorphs are clearly recycled into these sediments, yet the composition of assemblages recovered from individual samples shows these to lie in stratigraphic sequence, indicating that no mixing has occurred between closely spaced samples. The inference is that the sediments were deposited very close to the eroding source rocks (Truswell et al. 1999). In all probability, these source rocks underlie the Quaternary cover in the immediate vicinity.

\section{SUMMARY AND CONCLUSIONS}

Sedimentary material recovered by dredging of the sea floor during the Antarctic cruises of the Australasian Antarctic Expedition of 1911-1914 continues to provide information that sheds light on the geology of the East Antarctic margin. During that expedition, dredge samples were recovered in a sweep of coastline extending from close to the main base at Commonwealth Bay, to the western edge of the Shackleton Ice Shelf. Bottom sediments recovered during the dredging were shown to yield palynomorphs that have been recycled from eroding sedimentary sequences. Some 53 dredge samples were examined for their palynomorph content in an earlier study (Truswell 1982). That study, published in the centenary of Mawson's birth, showed high concentrations in three regions of the continental shelf, namely, offshore from the Shackleton Ice Shelf, from Cape Carr, and from close to the Mertz Glacier.

In the centenary year of the departure of the expedition, the findings of the earlier study have been re-evaluated in the light of new information that has accumulated in relation to the bathymetry of the sampled areas of the continental shelf, the sub-ice topography of ice shelves and the Antarctic interior, and of the sedimentary processes controlling the movement of palynomorphs in sea-floor sediments. In brief, the main results of the present survey are as follows:

1. The most productive samples, yielding densities of 1500-2000 grains per gram of sediment, occur near the seaward end of the Shackleton Ice Shelf. The age groups represented include Early and Late Permian, Late Jurassic- 
Early Cretaceous (including Albian) and Late CretaceousEarly Cenozoic palynomorphs, all showing excellent preservation. The Permian element in particular is better preserved than any previously described from Antarctica, suggesting neither deep burial nor thermal metamorphism. While the source of such material remains speculative, recent reconstructions suggest that Australia and Antarctica may have been conjoined in the region of the southern Perth Basin, where thick Permian and Triassic sequences occur. Hence sediments of this age might not be unexpected in this sector of Antarctica. Further, the Darling Fault of the Perth Basin may correlate with the Denman and Scott glaciers. New data on sub-ice topography shows the Denman Glacier to be one of the major drainage outlets flowing into the Shackleton Ice Shelf, and suggest that it may have connections with the deep Aurora Subglacial Basin of the interior. Hence, there is a possibility that the source of the Permian material may lie within this interior basin.

2. Samples collected on the continental shelf to the west of the Mertz Glacier are now shown to lie mostly on the edge of the steep trough that is the George V Basin. New echo-sounding data has clarified the bathymetry of this feature, which is typical of similar features in other areas of the Antarctic continental shelf. Recycled palynomorphs present in these samples suggest the presence of eroding sequences of Early Cretaceous (as young as Aptian) age, in addition to Late Cretaceous through Cenozoic sequences. The previous suggestion that these sequences may correlate with those of the Otway Basin on the Australian margin is corroborated by recent seismic reflection data showing the presence of thick rift and pre-rift sequences offshore from the Adélie and Wilkes coasts.

Previous suggestions that Mesozoic and Cenozoic sediments on this part of the Antarctic margin may be related to sediment fill in the extensive Wilkes Basin of the inland need to be reassessed in the light of better understanding of the nature of that basin, based on fresh aeromagnetic and airborne radar surveys. These suggest that there is little likelihood of any significant thickness of post-Jurassic sediments in that basin, although the possibility that small Mesozoic basins might lie in the western part of the major basin cannot be ruled out.

3. While it is difficult to generalise about the factors controlling the erosion of palynomorphs from sedimentary sequences that either crop out on the sea floor or lie beneath glacial cover, two studies - one in the Ross Sea, another on the Mac.Robertson Shelf - indicate that there has been little movement of the microfossils by current action after their deposition on the sea floor. These studies, although areally restricted, increase confidence in the value of this recycled material as a tool in identifying the proximity of source rocks.

\section{ACKNOWLEDGEMENTS}

Professor P.G. Quilty encouraged my participation in the conference Mawson 100 years on; how things have changed, in Hobart in 2011 at which this paper was presented. I acknowledge the Research School of Earth Sciences at the Australian National University for the award of a Visiting Fellowship. Clive Hilliker, of the Fenner School of Environment and Society, ANU, was an able draughtsman. I thank Judith Shelley for reading the draft manuscript. At Geoscience Australia I am grateful to Alix Post, Jodie Smith,
Peter Harris and Chris Carson for discussions and for provision of some of the illustrations.

\section{REFERENCES}

Batten, D.J. 1991: Reworking of plant microfossils and sedimentary provenance. In Morton, A.C., Todd, S.P. \& Haughton, P.D.W. (eds): Developments in sedimentary provenance studies. Geological Society Special Publication 57: 79-90.

Bayley, P.G.W. \& Stllwell, F.L. 1923: The Adélie Land meteorite. Australasian Antarctic expedition 1911- 1914. Scientific Reports Series A, 4: 1-15.

Beaman, R.J. \& Harris, P.T. 2003: Seafloor morphology and acoustic facies of the George V Land Shelf. Deep Sea Research II 50: 1343-1355.

Beaman, R.J., O’Brien, P.E., Post, A.L. \& De Santis, L. 2010: A new high-resolution model for the Terre Adélie and George V continental margin, East Antarctica. Antarctic Science 23: 95-103.

Bijl, P.K., Pross, J., Warnaar, J., Stickley, C.E., Huber, M., Guerstein, R., Houben, A.J.P., Sluis, A., Visscher, H. \& Brinkhuis, H. 2011: Environmental forcings of Paleogene Southern Ocean dinoflagellate biogeography. Paleoceanography 26, PA1202, doi:10.1029/2009PA001905.

Brown, B.J., Muller, R.D., Gaina, C., Struckmeyer, H.I.M., Stagg, H.M.J. \& Symonds, P.A. 2003: Formation and evolution of Australian passive margins: implications for locating the boundary between continental and oceanic crust. In Hillis, R.R. \& Muller, R.D. (eds): Evolution and Dynamics of the Australian Plate. Geological Society of America Special Paper 372: 223-243.

Browne, W.R. 1923: The dolerites of King George Land and Adélie Land. Australasian Antarctic Expedition 19111914. Scientific Reports, Series A, 3: 246-260.

Chapman, F. 1922: Sea-floor deposits from soundings. Australasian Antarctic Expedition 1911-14. Scientific Reports, Series A, 2: 1-60.

Close, D.J., Stagg, H.M.J. \& O'Brien, P.E. 2007: Seismic stratigraphy and sediment distribution on the Wilkes Land and Terre Adélie margins, East Antarctica. Marine Geology 239: 33-57.

Coulson, A.L. 1925: Magnetite garnet rocks from the moraines at Cape Denison, Adélie Land. Australasian Antarctic Expedition 1911-1914. Scientific Reports, Series A, 3: 281-307.

Davis, J.K. 1939: Soundings. Australasian Antarctic Expedition 1911-1914. Reports, Series A, 2, Part 3: 87-102.

Domack, E.W. 1982: Sedimentology of glacial and glacial marine deposits on the George V- Adélie continental shelf, East Antarctica. Boreas 11: 79-97.

Domack, E.W. 1985: Glacial erosion on the George V/Adélie continental margin, East Antarctica. Antarctic Journal of the United States 19: 76-78.

Domack, E.W., Fairchild, W.W. \& Anderson, J.B. 1980: Lower Cretaceous sediment from the East Antarctic continental shelf. Nature 287: 625-626.

Drewry, D.J. 1976: Sedimentary basins of the East Antarctic craton from geophysical evidence. Tectonophysics 36: 301-314.

Ferraccioli, F., Armadillo, E., Jordan, T., Bozzo, E. \& Corr, H. 2009: Aeromagnetic exploration over the East Antarctic ice sheet: A new view of the Wilkes Subglacial Basin. Tectonophysics 478: 62-77.

Fitzsimons, I.C.W. 2003: Proterozoic basement provinces of southern and southwestern Australia and their correlation with Antarctica. In Yoshida, M., Windley, B.F. \& Dasgupta, S. (eds): Proterozoic East Gondwana; supercontinent assembly and breakup. Geological Society of London Special Publication 206: 93-130. 
Foster, C.B., Balme, B.E. \& Helby, R. 1994: First record of Tethyan palynomorphs from the Late Triassic of East Antarctica. AGSO Journal of Geology \& Geophysics 15: 239-246.

General Bathymetric Map of the Oceans 2008: GEBCO _ 08 Grid. version 20100927. http://www.gebco.net.

Glastonbury, J.O.G. 1940: Certain epidotic rocks from the moraines at Commonwealth Bay. Australasian Antarctic Expedition 1911-1914. Scientific Reports Series A, 4: 183-196.

Goodge, J.W. \& Fanning, C.M. 2010: Composition and age of the East Antarctic Shield in eastern Wilkes Land determined by proxy from Oligocene - Pleistocene glaciomarine sediment and Beacon Supergroup sandstones, Antarctica. Geological Society of America Bulletin 122: 1135-1159.

Helby, R., Morgan, R. \& Partridge, A.D. 1987: A palynological zonation of the Australian Mesozoic. Association of Australasian Palaeontologists, Memoir 4: 1-94.

Hince, B. (ed.) 2012: Still no Mawson: Frank Stillwell's Antarctic diaries 1911-1913. Australian Academy of Science, Canberra.

Levy, R.H. \& Harwood, D.M. 2000: Tertiary marine palynomorphs from the Mcmurdo Sound erratics, Antarctica. In Stilwell, J.D. \& Feldmann, R.M. (eds): Paleobiology and Paleoenvironments of Eocene Rocks, McMurdo Sound, Antarctica. American Geophysical Union, Antarctic Research Series, 76: 183-242.

Lythe, M.B., Vaughan, D.G. \& the BEDMAP Consortium 2001: BEDMAP: a new ice thickness and subglacial topographic model of Antarctica. Journal of Geophysical Research 106: 11335-11351.

McGowran, B., Archer, M., Bock, P., Darragh, T.A., Godthelp, H., Hageman, S., Hand, S.J., Hill, R., Li, Q., Maxwell, P.A., McNamara, K.J., Macphail, M., Mildenhall, D., Partridge, A.D., Richardson, J., Shafik, S., Truswell, E.M. \& Warne, M. 2000: Australasian palaeobiogeography: the Palaeogene and Neogene record. Memoir of the Association of Australasian Palaeontologists 23: 405-470.

Mawson, D. 1914: Australasian Antarctic Expedition, 1911-1914. The Geographical Journal, 44 (3): 258-284.

Mawson, D. 1915: The Home of the Blizzard (first published by Heinemann, London). Edition published 2010, Wakefield Press, Adelaide: $536 \mathrm{pp}$

Mawson, D. 1940a: Sedimentary Rocks. Australasian Antarctic Expedition 1911-1914. Scientific Reports, Series A, 4: 347-367.

Mawson, D. 1940b: Catalogue of Rocks and Minerals collected in Antarctic Lands. Australasian Antarctic Expedition 1911-1914. Scientific Reports, Series A, 4: 405-432.

Mawson, D. 1942: Narrative and Cartography. Australasian Antarctic Expedition 1911-1914. Scientific Reports Series $A, \mathbf{1}: 1-492$.

Morgan, R., Rowett, A.I. \& White, M.R. 1995: Biostratigraphy. Great Australian Bight. Petroleum Geology of South Australia 5. South Australian Government: 1-46.

Playford, G. 1990: Proterozoic and and Paleozoic palynology of Antarctica: a review. In Taylor, T.N. \& Taylor, E.L. (eds): Antarctic Paleobiology. Its Role in the Reconstruction of Gondwana. Springer Verlag, New York: 51-70.

Roberts, J.L., Warner, R.C., Young, D., Wright, A., van Ommen, T.D., Blankenship, D.D., Seigert, M., Young, N.W., Tabacco, I.E., Forieri, A., Passerini, A., Zirizotti, A. \& Frezzotti, A. 2011: Refined broad-scale morphology of Aurora Subglacial Basin, East Antarctica derived by an ice-dynamics-based interpolation scheme. The Cryosphere Discussions 5: 655-684.

Schrum, H., Domack, E., Desantis, L., Leventer, A., McMullen, K., Escutia, C. 2004: A glimpse at Late Mesozoic to Early Tertiary offshore stratigraphy from Wilkes Land, East
Antarctica: Results of strategic dredging of the MertzNinnis Trough. American Geophysical Union, Fall Meeting, Abstract PP51E-1359.

Steed, R.H.N. \& Drewry, D.J. 1982: Radio echo-sounding investigations of Wilkes Land, Antarctica. In Craddock, C. (ed.): Proceedings of the 3rd International Symposium on Antarctic Geology and Geophysics. University of Wisconsin Press: 969-975.

Stillwell, F.L. 1918: The metamorphic rocks of Adélie Land. Australasian Antarctic Expedition 1911-1914. Scientific Reports, Series A, 3: 1-266.

Stillwell, F.L. 1923: Amphibolites and related rocks from the moraines, Cape Denison. Australasian Antarctic Expedition 1911-1914. Scientific Reports, Series A, 3: 261-280.

Summers, H.S. \& Edwards, A.B. 1940: Granites of King George Land and Adélie Land. Australasian Antarctic Expedition 1911-1914. Scientific Reports Series A, 4: 87-113.

Truswell, E.M. 1982: Palynology of sea-floor samples collected by the 1911-1914 Australasian Antarctic Expedition: implications for the geology of coastal East Antarctica. Journal of the Geological Society of Australia 29: 343-356.

Truswell, E.M. 1983: Recycled Cretaceous and Tertiary pollen and spores in Antarctic marine sediments: a catalogue. Palaeontographica Abt.B 186: 121-174.

Truswell, E.M. 1991: Data report: Palynology of sediments from Leg 119 drillsites in Prydz Bay, East Antarctica. In Barron, J., Larsen, B. et al.: Proceedings of the Ocean Drilling Program, Scientific Results, 119: 941-945.

Truswell, E.M. 1999: Palynomorph assemblages from marine Eocene sediments on the west Tasmanian continental margin and the South Tasman Rise. Australian Journal of Earth Sciences 44: 633-654.

Truswell, E.M. \& Drewry, D.J. 1984: Distribution and provenance of recycled palynomorphs in surficial sediments of the Ross Sea, Antarctica. Marine Geology 59: 187-214.

Truswell, E.M., Dettmann, M.E. \& O’Brien, P.E. 1999: Mesozoic palynofloras from the Mac. Robertson Shelf, East Antarctica: geological and phytogeographic implications. Antarctic Science 11: 239-255.

Truswell, E.M. \& Macphail, M.K. 2009: Polar forests on the edge of extinction: what does the spore and pollen evidence from East Antarctica say? Australian Systematic Botany 22: 57-106.

Urbini, S., Cafarella, L., Zirizzotti, A., Tabacco, I.E., Bottari, C., Baskaradas, J.A. \& Young, N. 2010: Radio echo sounding data analysis of the Shackleton Ice Shelf. Annals of Geophysics 53: 79-87.

Vanney, J.R. \& Johnson, G.L. 1979: Wilkes Land continental margin physiography, East Antarctica. Polar Forschung 49: 20-29.

Veevers, J.J. \& Saeed, A. 2011: Age and composition of Antarctic bedrock reflected by detrital zircons, erratics, and recycled microfossils in the Prydz Bay-Wilkes Land-Ross Sea-Marie Byrd Land sector $\left(70^{\circ}-240^{\circ}\right.$ E). Gondwana Research 20: $710-738$.

Wagstaff, B.E., Gallagher, S.J. \& Trainor, J.K. 2012: A new subdivision of the Albian spore-pollen zonation of Australia. Review of Palynology and Palaeobotany 171: 57-72.

Wilkes, C. 1844: Narrative of the United States Exploring Expedition during the years 1838, 1839, 1840, 1841, 1842. Vols 1-5. C. Sherman, Philadephia.

Wrenn, J.H. \& Hart, G.F. 1988: Palaeogene dinoflagellate cyst biostratigraphy of Seymour Island, Antarctica. Geological Society of America Memoir 169: 321-447.

(accepted 4 September 2012) 